\title{
The Colorado River and its Deposits Downstream from Grand Canyon in Arizona, California, and Nevada
}

By Ryan S. Crow, Debra Block, Tracey J. Felger, P. Kyle House, Philip A. Pearthree, Brian F. Gootee, Ann M. Youberg, Keith A. Howard, and L. Sue Beard

Open-File Report 2018-1005

U.S. Department of the Interior U.S. Geological Survey 


\section{U.S. Department of the Interior \\ RYAN K. ZINKE, Secretary}

\section{U.S. Geological Survey \\ William H. Werkheiser, Deputy Director \\ exercising the authority of the Director}

U.S. Geological Survey, Reston, Virginia: 2018

For more information on the USGS-the Federal source for science about the Earth, its natural and living resources, natural hazards, and the environment-visit https://www.usgs.gov/ or call 1-888-ASK-USGS (1-888-275-8747).

For an overview of USGS information products, including maps, imagery, and publications, visit https://store.usgs.gov/.

Any use of trade, firm, or product names is for descriptive purposes only and does not imply endorsement by the U.S. Government.

Although this information product, for the most part, is in the public domain, it also may contain copyrighted materials as noted in the text. Permission to reproduce copyrighted items must be secured from the copyright owner.

Suggested citation:

Crow, R.S., Block, D., Felger, T.J., House, P.K., Pearthree, P.A., Gootee, B.F., Youberg, A.M., Howard, K.A., and Beard, L.S., 2018, The Colorado River and its deposits downstream from Grand Canyon in Arizona, California, and Nevada: U.S. Geological Survey Open-File Report 2018-1005, 6 p., https://doi.org/10.3133/ofr20181005.

ISSN 2331-1258 (online) 


\section{Contents}

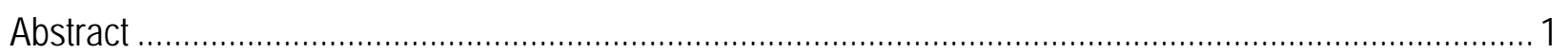

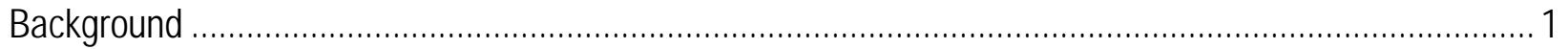

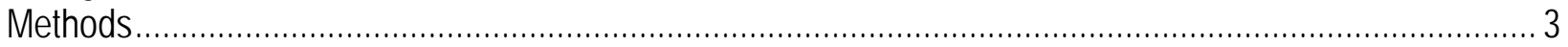

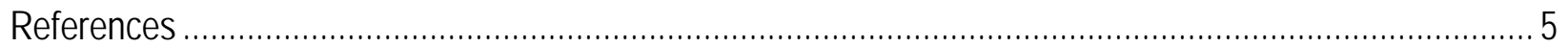

\section{Figure}

1. Map showing the study area and the distribution of select strata of the LOCO Group from new and

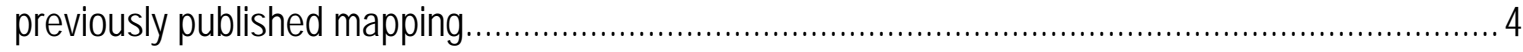




\title{
The Colorado River and Its Deposits Downstream from Grand Canyon in Arizona, California, and Nevada
}

By Ryan S. Crow ${ }^{1}$, Debra Blockㄹ, Tracey J. Felger ${ }^{1}$, P. Kyle House ${ }^{1}$, Philip A. Pearthree ${ }^{2}$, Brian F.Gootee ${ }^{2}$, Ann M. Youberg², Keith A. Howard ${ }^{1}$, and L. Sue Beard ${ }^{1}$

\begin{abstract}
Understanding the evolution of the Colorado River system has direct implications for (1) the processes and timing of continental-scale river system integration, (2) the formation of iconic landscapes like those in and around Grand Canyon, and (3) the availability of groundwater resources. Spatial patterns in the position and type of Colorado River deposits, only discernible through geologic mapping, can be used to test models related to Colorado River evolution. This is particularly true downstream from Grand Canyon where ancestral Colorado River deposits are well-exposed. We are principally interested in (1) regional patterns in the minimum and maximum elevation of each depositional unit, which are affected by depositional mechanism and postdepositional deformation; and (2) the volume of each unit, which reflects regional changes in erosion, transport efficiency, and accommodation space. The volume of Colorado River deposits below Grand Canyon has implications for groundwater resources, as the primary regional aquifer there is composed of those deposits. To this end, we are presently mapping Colorado River deposits and compiling and updating older mapping. This preliminary data release shows the current status of our mapping and compilation efforts. We plan to update it at regular intervals in conjunction with ongoing mapping.
\end{abstract}

\section{Background}

Ongoing geologic mapping campaigns in the lower Colorado River corridor (LOCO), led by the U.S. Geological Survey (USGS) and the Arizona Geological Survey (AZGS), are focused on the identification and characterization of Colorado River deposits in the corridor between Hoover and Imperial Dams, in Nevada, California, and Arizona (fig. 1). Although these deposits have been studied for nearly 150 years (for example, Ives, 1861; Lee, 1908; Blackwelder, 1934; Longwell, 1936), there is continuing interest in the processes of river integration (for example, House and others, 2008; McDougall and Martinez, 2014; Spencer and others, 2013), the effect of tectonics and climate on Colorado River evolution (for example, Lucchitta, 1979; Malmon and others, 2011; Howard and others, 2015; Thacker and others, 2017), the timing of landscape evolution (for example, Howard and others, 2015; Kimbrough and others, 2015), and the extent of the aquifers housed in Colorado River deposits (for example, Owen-Joyce and others, 2000; Wiele and others, 2008). These ongoing research topics are greatly informed by detailed outcropscale studies, analytical studies, and an understanding of the regional patterns in the extent of

\footnotetext{
${ }^{1}$ U.S. Geological Survey.

${ }^{2}$ Arizona Geological Survey.
} 
Colorado River deposits. Field and subsurface observations (for example, Metzger, 1968; Buising, 1990; House and others, 2005; House and others, 2008; Pearthree and House, 2014; Gootee and others, 2016), and geochronology (for example, House and others, 2008; Dorsey and others, 2011; Sarna-Wojcicki and others, 2011) have led to an increasingly refined understanding of the sequence and timing of river incision and deposition in the area. The main stratigraphic packages deposited by the Colorado River have been grouped by House (2016) as the LOCO strata, which includes (from oldest to youngest): the Bouse Formation, the Bullhead Alluvium, the Palo Verde alluvium, the Chemehuevi Formation, the Riverside alluvium (not yet included in our LOCO group compilation), and the Blythe alluvium. This new stratigraphic framework builds on the seminal work of Metzger (Metzger, 1968; Metzger and others, 1973; Metzger and Loeltz, 1973).

The Bouse Formation consists of carbonates and interbedded siliciclastic mud and sand, including abundant Colorado Plateau derived grains that were deposited as the Colorado River filled and spilled southward through a series of formerly internally drained basins to the protoGulf of California (Metzger, 1968; Buising, 1990; House and others, 2008; Pearthree and House, 2014; Spencer and others, 2013; Kimbrough and others, 2015). Previous work indicates a maximum age for the Bouse Formation in Cottonwood and Mohave valleys of 5.6 Ma (House and others, 2008). Farther south in the Blythe basin, the upper part of the Bouse Formation is 4.8 Ma based on an interbedded ash (Sarna-Wojcicki and others, 2011; Harvey, 2014). The base of the formation in the Blythe basin may be as old as 6 Ma based on the last occurrences of marine foraminifera species (McDougall and Martinez, 2014). The approximately 4.5 to 3.5 Ma Bullhead Alluvium records the deposition of fluvial gravel, sand, and minor mud during aggradation of a >200-meter-thick aggradation package that followed the establishment of a graded river profile between the Grand Wash trough and the proto-Gulf of California (House and others, 2005; Howard and others, 2015). The Palo Verde alluvium is lithologically similar to the Bullhead Alluvium, but contains rounded petrified wood that is interpreted to be reworked out of the Bullhead Alluvium (House, 2016); the geomorphic expression of these deposits is consistent with post-Bullhead Alluvium terrace remnants. Although the age of the Palo Verde alluvium is indeterminate, its landscape position indicates an age between that of the Bullhead Alluvium and the Chemehuevi Formation. The $\sim 70$ ka Chemehuevi Formation is an approximately 100-meterthick aggradation package composed of mud and sand. Its origin has been debated, but is probably related to climatic fluctuations (Malmon and others, 2011). The Riverside alluvium is composed of relatively thin veneers over a series of cut terraces linked to brief periods of stability while the river incised the Chemehuevi fill and underlying strata (House, 2016). Finally, the Blythe alluvium forms the Holocene to modern flood plain and subaqueous sediments of the Colorado River channel bed (House, 2016).

One of our main goals is the mapping of these units and the adjacent piedmont deposits in the LOCO area. We are conducting new mapping and incorporating existing mapping into the newly defined stratigraphic framework. Our initial efforts have focused on the LOCO strata in the area between Hoover and Imperial Dams, although some mapping in the Lake Mead area and south of the Chocolate Mountains was also either conducted or compiled. The digital database presented here contains new mapping and compilation efforts to date (fig. 1). Future work will focus on the incorporation of the Riverside alluvium. We are also in the process of using this database to test hypotheses about post-6 Ma deformation in the area and the depositional processes of the Bouse Formation. Here we present only the new mapping and mapping compilation for other researchers and stakeholders to use as our study continues. 


\section{Methods}

This section summarizes the methods used in the map compilation, which are explained in more detail in the metadata. Geologic units were extracted from published and unpublished mapping, including map unit polygons from in-progress USGS and AZGS mapping campaigns (see the metadata for a complete list of map references). We only incorporated mapping at scales of 1:150,000 or greater (more detailed) and created separate feature classes to aggregate map units by original mapping scale. The source dataset of each polygon was recorded, as well as the original map unit designation. We then assigned each polygon to a stratigraphic unit-Bouse Formation, Bullhead Alluvium, Palo Verde alluvium, Chemehuevi Formation, or Blythe alluvium - in our new stratigraphic framework (House, 2016). When possible, these units were further subdivided based on facies. In some cases, previous mapping was reassigned to other stratigraphic units based on field observations or analytical data. For example, certain outcrops of the Muddy Creek deposits in the western Lake Mead area were here assigned to the Bouse Formation(?) based on the presence of the 5.6 Ma ash of Wolverine Creek (Castor and Faulds, 2001) and ${ }^{87} \mathrm{Sr} /{ }^{86} \mathrm{Sr}$ data (Roskowski and others, 2010). Where pre-existing mapping was known to include multiple stratigraphic units of interest, those polygons were assigned to the dominant unit and the map unit was queried. We also noted when the units of interest were interbedded or grouped with piedmont deposits. During compilation, where mapping overlapped, we excluded (1) older mapping that did not benefit from recent advances in the understanding of Colorado River stratigraphy, (2) mapping that was less detailed, (3) incomplete mapping (even if it was more detailed), and (4) duplicate polygons of the same geometry. Polygons sometimes had to be split at map boundaries so that only part of a polygon could be included in the compilation. Our resulting compilation contains a single polygon feature class for each map unit, derived from the most accurate and detailed mapping. Consequently, the original scale of map units in our compilation will vary spatially. Again, we plan to update this product at regular intervals in conjunction with ongoing mapping. 


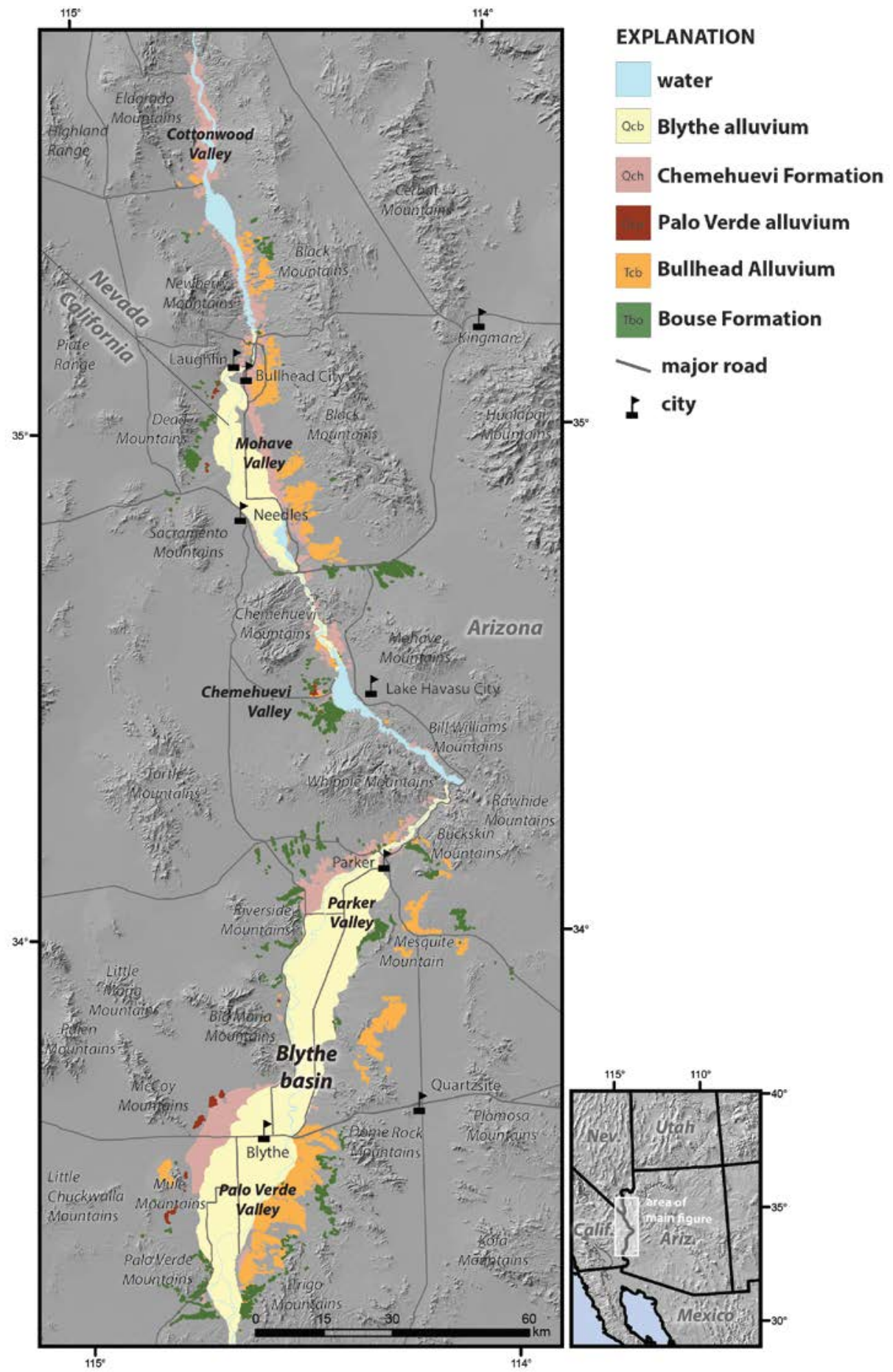

Base derived from U.S. Geological Survey 10-m NED elevation data Universal Transverse Mercator projection

Figure 1. Map showing the study area and the distribution of select strata of the lower Colorado River corridor (LOCO) group from new and previously published mapping. Future efforts will focus on the incorporation of the Riverside alluvium (post-Chemehuevi Formation), continued new mapping, and remapping where needed. 


\section{References}

Blackwelder, E., 1934, Origin of the Colorado River: Bulletin of the Geological Society of America, v. 45, no. 1-3, p. 551-565.

Buising, A.V, 1990, The Bouse Formation and bracketing units, southeastern California and western Arizona-Implications for the evolution of the proto-Gulf of California and the lower Colorado River: Journal of Geophysical Research-Solid Earth and Planets, v. 95, no. B12, p. 20111-20132.

Castor, S.B., and Faulds, J.E., 2001, Post-6 Ma limestone along the southeastern part of the Las Vegas Valley Shear Zone, Southern Nevada, in Young, R.A., and Spamer, E.E., eds., Colorado River-Origin and evolution: Grand Canyon, Arizona, Grand Canyon Association Monograph 12, p. 77-79.

Dorsey, R.J., Housen, B.A., Janecke, S.U., Fanning, C.M., and Spears, A.L.F., 2011, Stratigraphic record of basin development within the San Andreas fault system-Late Cenozoic Fish Creek-Vallecito basin, southern California: Geological Society of America Bulletin, v. 123, no. 5-6, p. 771-793.

Gootee, B.F., Pearthree, P.A., House, P.K., Youberg, A., Spencer, J.E., and O’Connell, B., 2016, Geologic map and report of the Cibola area, La Paz County, Arizona, and Imperial County, California: Arizona Geological Survey Digital Geologic Map 112 (DGM-112), 1:24,000, 21 p.

Harvey, J., 2014, Zircon age and oxygen isotopic correlations between Bouse Formation tephra and the Lawlor Tuff: Geosphere, v. 10, no. 2, p. 221-232.

House, P.K., 2016, The LOCO Strata-New observations, mapping, discoveries, and ideas about key geologic deposits chronicling the inception and evolution of the lower Colorado River from the Pliocene to the present, in Reynolds, R.E,. ed., Going LOCO, investigations along the Lower Colorado River: California State University Desert Studies Consortium, p. 65-72.

House, P.K., Pearthree, P.A., Howard, K.A., Bell, J.W., Perkins, M.E., Faulds, J.E., and Brock, A.L., 2005, Birth of the lower Colorado River-Stratigraphic and geomorphic evidence for its inception near the conjunction of Nevada, Arizona, in Pederson, J., and Dehler, C.M., eds., Interior western United States: Geological Society of America Field Guide 6, p. 357-387.

House, P.K., Pearthree, P.A., and Perkins, M.E., 2008, Stratigraphic evidence for the role of lake spillover in the inception of the lower Colorado River in southern Nevada and western Arizona, in Reheis, M., Hershler, R., and Miller, D., eds., Late Cenozoic drainage history of the southwestern Great Basin and lower Colorado River region-Geologic and biotic perspectives: Geological Society of America Special Paper 439, p. 335-353.

Howard, K.A., House, P.K., Dorsey, R.J., and Pearthree, P.A., 2015, River-evolution and tectonic implications of a major Pliocene aggradation on the lower Colorado River-The Bullhead Alluvium: Geosphere, v. 11, no. 1, p. 1-30.

Ives, J.C., 1861, Report upon the Colorado River of the West: Government Printing Office, Washington D.C., 154 p.

Kimbrough, D.L., Grove, M., Gehrels, G.E., Dorsey, R.J., Howard, K.A., Lovera, O., Aslan, A., House, P.K., and Pearthree, P.A., 2015, Detrital zircon U-Pb provenance of the Colorado River-A 5 m.y. record of incision into cover strata overlying the Colorado Plateau and adjacent regions: Geosphere, v. 11, no. 6, p. 1719-1748.

Lee, W.T., 1908, Geologic reconnaissance of a part of western Arizona: U.S. Geological Survey Bulletin 352, 96 p. 
Longwell, C.R., 1936, Geology of the Boulder Reservoir floor, Arizona-Nevada: Bulletin of the Geological Society of America, v. 47, p. 1393-1476.

Lucchitta, I., 1979, Late Cenozoic uplift of the southwestern Colorado Plateau and adjacent lower Colorado River region: Tectonophysics, v. 61, no. 1-3, p. 63-95.

Malmon, D.V., Howard, K.A., House, P.K., Lundstrom, S.C., Pearthree, P.A., Sarna-Wojcicki, A.M., Wan, E., and Wahl, D.B., 2011, Stratigraphy and depositional environments of the upper Pleistocene Chemehuevi Formation along the lower Colorado River: U.S. Geological Survey Professional Paper 1786, 95 p.

McDougall, K., and Martinez, A., 2014, Evidence for a marine incursion along the lower Colorado River: Geosphere, v. 10, no. 5, p. 842-869.

Metzger, D.G., 1968, The Bouse Formation (Pliocene) of the Parker-Blythe-Cibola area, Arizona and California, in Geological Surevey Research, 1968: U.S. Geological Survey Professional Paper 600-D, p. D126-D136.

Metzger, D.G., and Loeltz, O.J., 1973, Geohydrology of the Needles area, Arizona, California, and Nevada: U.S. Geological Survey Professional Paper 486-J, p. 1-54.

Metzger, D.G., Loeltz, O.J., and Irelna, B., 1973, Geohydrology of the Parker-Blythe-Cibola area, Arizona and California: U.S. Geological Survey Professional Paper 486-G, p. 1-130.

Owen-Joyce, S.J., Wilson, R.P., Carpenter, M.C., and Fink, J.B., 2000, Method to identify wells that yield water that will be replaced by water from the Colorado River downstream from Laguna Dam in Arizona and California: U.S. Geological Survey Water-Resources Investigation Report 00-4085, 31 p.

Pearthree, P.A., and House, P.K., 2014, Paleogeomorphology and evolution of the early Colorado River inferred from relationships in Mohave and Cottonwood valleys, Arizona, California, and Nevada: Geosphere, v. 10, no. 6, p. 1139-1160.

Roskowski, J.A., Patchett, P.J., Spencer, J.E., Pearthree, P.A., Dettman, D.L., Faulds, J.E., and Reynolds, A.C., 2010, A late Miocene-early Pliocene chain of lakes fed by the Colorado River-Evidence from Sr, C, and O isotopes of the Bouse Formation and related units between Grand Canyon and the Gulf of California: Geological Society of America Bulletin, v. 122, no. 9-10, p. 1625-1636.

Sarna-Wojcicki, A.M., Deino, A.L., Fleck, R.J., Mclaughlin, R.J., Wagner, D., Wan, E., Wahl, D., Hillhouse, J.W., and Perkins, M.E., 2011, Age, composition, and areal distribution of the Pliocene Lawlor Tuff , and three younger Pliocene tuffs, California and Nevada: Geosphere, v. 7, no. 3, p. 599-628.

Spencer, J.E., Patchett, P.J., Pearthree, P.A., House, P.K., Sarna-Wojcicki, A.M., Wah, E., Roskowski, J.A., Faulds, J.E., and Wan, E., 2013, Review and analysis of the age and origin of the Pliocene Bouse Formation, lower Colorado River Valley, southwestern USA: Geosphere, v. 9, no. 3, p. 444-459.

Thacker, J.O., Karlstrom, K.E., Crossey, L.J., Crow, R., Beard, L.S., and Dorsey, R.J., 2017, Hypothesis for post-Bouse distributed deformation of the Lower Colorado River corridor, in Reynolds, R.E., ed., ECSZ does it-Revisiting the Eastern California Shear Zone: 2017 Desert Symposium, p. 158-164.

Wiele, S.M., Leake, S.A., Owen-Joyce, S.J., and McGuire, E.H., 2008, Update of the accounting surface along the lower Colorado River: U.S. Geological Survey Scientific Investigations Report 2008-5113, 16 p. 